\title{
How do primary health care professionals deal with pregnant women who are victims of domestic violence?
}

\author{
Dora Mariela Salcedo-Barrientos ${ }^{1}$ \\ Paula Orchiucci Miura ${ }^{2}$ \\ Vanessa Dias Macedo ${ }^{3}$ \\ Emiko Yoshikawa Egry ${ }^{4}$
}

Objectives: to determine how Family Health Strategy professionals recognize and deal with domestic violence in pregnant women. Method: qualitative study based on the Theory of Praxis Intervention in Collective Health Nursing (TIPESC). Fourteen professionals at a Basic Health Unit in the east side of Sao Paulo/Brazil were interviewed. Empirical data were categorized and discussed in thematic groups. For data analysis was used the technique of Discourse Analysis. Results: we identified low number of reported cases of domestic violence; lack of education and training of health care professionals; failure in the identification and intervention process due to bias on their personal problems, moral attitudes and prejudice against these women. In addition, the study showed that their labor process was based entirely on the biological aspects of the women and to overcome this, they need of proper rapport between health care professionals and pregnant women to deal with of domestic violence. Conclusion: professionals should develop skills to intervene in violence against pregnant women and also modify labor processes considering women in their totality and part of society.

Descriptors: Women's Health; Domestic Violence; Health Personnel; Prenatal Care.

\footnotetext{
${ }^{1} \mathrm{PhD}$, Professor, Escola de Artes, Ciências e Humanidades, Universidade de São Paulo, São Paulo, SP, Brazil.

2 Post-doctoral fellow, Instituto de Psicologia, Universidade de São Paulo, São Paulo, SP, Brazil.

${ }^{3}$ Midwife.

${ }^{4}$ PhD, Full Professor, Escola de Enfermagem, Universidade de São Paulo, São Paulo, SP, Brazil.
}

Corresponding Author:

Dora Mariela Salcedo Barrientos

Universidade de São Paulo. Escola de Artes, Ciências e Humanidades

Rua Arlindo Béttio, 1000

Bairro: Ermelino Matarazzo

CEP: 03828-000, São Paulo, SP, Brasil

E-mail: dorabarrientos@usp.br
Copyright (c) 2014 Revista Latino-Americana de Enfermagem This is an Open Access article distributed under the terms of the Creative Commons Attribution Non-Commercial License (CC BY-NC).

This license lets others distribute, remix, tweak, and build upon your work non-commercially, and although their new works must also acknowledge you and be non-commercial, they don't have to license their derivative works on the same terms. 


\section{Introduction}

Violence during pregnancy and the postpartum period affects the quality of life of women. Healthcare professionals worry about perpetuation of the cycle of domestic violence and their consequences ${ }^{(1-2)}$. Pregnant women endured the worst kind of violence as compared to other periods of their lives ${ }^{(3)}$.

A study with 1.922 women between 15 and 49 years old in 14 public health services in greater Sao Paulo showed that $60 \%$ of pregnant women had been victims of violence (sexual, physical and psychological) inflicted by their intimate partners. Twenty percent of the women reported severe physical violence during their pregnancy, including punches, burns, verbal or gun threats $^{(3)}$. About one in five women reported violence during pregnancy ${ }^{(4)}$.

In Sao Paulo city, the Family Health Strategy (FHS) sponsor programs such as Mother Paulistana Program $^{(5)}$, which aims to assist pregnant women with prenatal consultations (at least seven), childbirth and postpartum evaluations throughout the first year of baby's life. The Program follows the guidelines of the Ministry of Health, which determines that professionals must "promote obstetric and neonatal care as well as specialized and humane for women and adolescents", and "promote attention to women and adolescents in situations of domestic and sexual violence"(6).

Nevertheless, violence against women has not yet become a priority in health services, due to health care to focus on the disease and the biological body ${ }^{(7)}$.

Strategies that prevent and solve domestic violence have been ineffective in Brazil. The scarce scientific production addressing domestic violence aggravates this problem. In fact, a reviewed by the Latin American Center for the Study of Violence and Health, identified that by $1990,3 \%$ of the academic production on violence in Brazil was produced before 1960, 11\% were in the 1970 s and $86 \%$ in the 1980 s. An improvement, however, it is still in a limited number.

The evidence provided by some studies and testimonials showed the need for trained professionals capable to recognize the needs of pregnant women and be sensitized to the relation between protective and destructive processes to which these women are subjected.

Taken all together, this study aimed to learn how FHS professionals recognized and dealt with pregnant women who experienced domestic violence.

\section{Methods}

This was a qualitative study based on the Theory of Praxis Intervention in Collective Health Nursing (TIPESC). TIPESC adopts the concept of social determinants of the health-disease process as an interpretive theory of phenomena, and systematic and dynamic intervention in the reality of working processes ${ }^{(8)}$.

An understanding between social relationships of production and access to material goods determine life in society, however, they are not sufficient to explain some phenomena occurring in the construction of social subjects. The gender category is able to illuminate the phenomenon of violence by bringing major advances in the theoretical and practical framework of health and nursing. Gender perspective, as a guiding praxis of health care, enables the overcoming of contradictions and transforming of reality ${ }^{(9)}$. In addition it amplifies the scope of the particular problems within collective health, specially in social relations, and identifying the current strengths in the family and society that determine the masculine and feminine ways of being.

The study setting was a Basic Health Unit (BHU), located on the east side of Sao Paulo/Brazil. The population in this BHU territory included 28,000 inhabitants. The average attendance in the $\mathrm{BHU}$ was 150 pregnant women/month.

After approval by the Ethics and Research Committee, empirical data were collected from January to March 2010. Seven FHS teams (14 professionals: 7 physicians and 7 nurses) were interviewed using a semi-structured script, which included questions about the advantages and difficulties in providing care in pregnant women who are victims of domestic violence. Health care professionals required higher education and needed to be part of the local health teams for at least 6 months in order to participate in this study. The BHU had seven teams and two members of each team were invited to participate in this study, i.e., a physician and a nurse, totaling 14 health care professionals and the saturation criterion was respected. The professionals who participated signed a consent form.

Data obtained through in-depth interviews were analyzed using Discourse Analysis of the themes in those statements.

This technique of analysis and treatment of primary source material was based on the proposed decoding of data based on the Discourse Theory ${ }^{(10)}$ - organization of narrative and discourse - from the perspective of dialectical materialism; the method was adapted to be 
used with complete discourses in order to capture the dialectical contradictions without losing the essence in question.

The analysis and treatment of the material consisted in extraction of the themes contained in those statements, looking for articulations between the themes and figures, their consistencies and ambiguities; analysis and interpretation for the capture of key contents contained in these statements.

All ethical guidelines were tended and this study was approved by the Research Ethics Committee at the University of Sao Paulo - USP, School of Nursing (Process n. 834/2009) and the Sao Paulo Municipal Health Secretary (Statement 17/10 CAAE: 0188.0.162.162-09).

After analysis, the following empirical categories emerged: domestic violence against pregnant adolescents, working process of health professionals, health needs of pregnant women in the family context and pregnancy and abortion

\section{Results and Discussion}

The health care professionals were between 28 and 62 years of age; most of them were females. All of them were graduates from private educational institutions in the State of São Paulo and Rio de Janeiro. These health care professionals were working in primary care from two to 35 years and from six months to seven years in the research location.

These health care professionals denied any formal education addressing issues of domestic violence during their undergraduate training. In postgraduate training, they took specialized courses in Family Health, Public Health, Occupational Medicine, Pediatrics, and Neonatology. These courses did not address the issues of violence despite the proximity of these topics to the problem.

Ah [...] I don't remember. I don't think so, there were lots of subjects on women's health at the nursing school, but I don't remember any about violence (E2).

Only one health care professional took an eighthour course and a 12-hour workshop on violence against women in general.

Health professions such as medicine, dentistry and nursing, do not include topics related to domestic violence in their syllabus or in their postgraduate education. Health care professionals are not prepared to take care of women who are victims of domestic violence $^{(11)}$.
Nurses, who spent most of their time in close contact with patients, find difficult to provide care to families and women who are victims of violence. Further they feel powerless to overcome those difficulties. Certainly, the lack of either preparatory courses or professional training in domestic violence hinders the confrontation of these issues ${ }^{(12)}$.

In addition to the lack of education and training in domestic violence, health care professionals have followed a fragmented training model in which they approach patients as a biological model with disregard of their biopsychosocial aspects and social determination itself of the health condition.

[...] we are very hurried, there's no time, for example, when I think the case needs a little special attention, I tell the nurse, see this case here (M6).

[...] in the public service we do not have time to think if there was some disease or not (M6).

These professionals' statements emphasize the concept of health acquired in professional schools by concentrating on biological issues and disease. This approach leaves women who suffer from violence without comprehensive health care needs. Thus, health care professionals do fragmentate their actions and objectives at work; and reduce their attention only to the biomedical aspects of care(13).

Actually this story (of violence) we learn from the health agent (E7).

This particular professional has little understanding of the problem with little comprehensiveness and minimizes the problem up to a point that makes it invisible to care. During the interviews, health care professionals declared that violence against pregnant women was non-existent. They did report cases of abandoned elderly and children with drug addicted parents.

I can identify some pathological risk, but not risk of violence (M6).

This invisibility of violence was reported in an American study which compared a group of $24 \%$ of women who experienced domestic violence seeking care in to the Emergency room, vs. another group of $28 \%$ of women seeking care in a primary care office and determined that only $6 \%$ of patients in each group were identified as victims of violence in these services ${ }^{(14)}$. A similar problem was identified in Brazil. Health care professionals tend to provide a biological and fragmented reductionism of care in their attention to women's health ${ }^{(13)}$.

This difficulty to identify and intervene in cases of violence against women is accentuated when women are pregnant. 
There's difficulty finding it because violence is complicated, violence against women [...], imagine against pregnant woman. I never had cases of violence against pregnant women (E7).

These attitudes indicate that health care services are moving away from the responsibility of addressing this population's problems. Pregnant women, in particular, are more vulnerable due to a debilitated health care system.

Health care professionals have many obstacles in order to identify and attend those patients involved in domestic violence. Some of those difficulties are the invisibility of the problem and lack of qualification of these professionals.

Other aspects such as life history, posture and professional attitudes potentiate the difficulties of professionals to assist users who are victims of domestic violence. These aspects signal an urgent need to discuss ethical and legal dilemmas which involve domestic violence and its mandatory report to the authorities ${ }^{(15)}$.

You know, we can't go deeper, we attend a lot of people [...] we can't (M6).

The FHS must function as an environment that enables health promotion and develop strategies to deal with health problems ${ }^{(16)}$.

Health care professionals feel unprepared to deal with teenage pregnancy much less with issues of domestic violence in pregnant adolescents.

Difficulty is the tension, even the women think they have to endure [...] and you see that sometimes a year goes by, another year comes, the same thing, they don't take any attitude, mainly women who depend on the husband or partner (E12).

But cases of violence I don't know, the nurse is the one who knows, I think it is because we are clinical, not familiar with obstetrics (M6).

Since there was a lack of preparation towards domestic violence, this group of health care professionals was judgmental and developed moralistic attitudes towards their patients. For instance, questioning motherhood in adolescents. Further, they had a distorted perception of violence. Thus, outcomes in this population were clearly affected. Here, we show a few sentences from these interviews:

The girls (adolescents) don't have a perspective on life, a dream, they don't think of studying, building a career, their dream is to be a mother (M9).

It is a form of violence for an adolescent to be a young mother, they lack maturity (M9).
Healthcare professionals saw this group of adolescents as immature girls without life prospects, and blamed them for their pregnancy. An important contradiction, however, was identified in these interviews. Since health care professionals made judgments only supported by common sense, they missed the opportunity to discuss questions about social production and reproduction of these adolescents.

Health care professionals who performed prenatal consultations were judgmental about family of pregnant teenagers. They considered these families to be dysfunctional and blamed the adolescents and their families for their pregnancy.

Ah [...] they (pregnant adolescents) are totally dysfunctional, none have a structured family, none of them (M8).

Some legal and regulatory documents discuss the conditions of pregnancy and pregnancy in adolescence. Ministry of Health states: there is not an ideal age for a woman to get pregnant, and claims that "although pregnancy in adolescents and young adults is not always desired, it can be a calm period on their lives, provided that the pregnant women are supported by a health care team responsible for their prenatal consultations". During this stage of life, women undergo many hormonal, physical and psychological changes, so they require specialized attention with emphasis on these changes. Further, Ministry states: that in some cases "pregnancy in adolescents as a part of goals on life can become an element that reorganizes their lives, and not undermines it"(17). It is important to emphasize that the ministerial concept does not address the peculiarities of adolescence in relation to the social moment and historically experienced by these young people.

Statute of the Child and Adolescent (ECA) ensures universal access to prenatal and perinatal periods to pregnant women by the Unified Health System ${ }^{(18)}$. It also mandates to communicate to the Guardian Council the suspicion or confirmation of cases of violence.

Therefore, it is the duty of health care professionals along with the family, to provide comprehensive care for adolescents and to understand their individual values, as well as their social and health needs. Health care professional must also assume the role of a mediator between society and the health needs identified at service time. It is up to them to provide an increasingly careful service to these adolescents, in order to meet the needs that permeate from their environment and people from where these adolescents come, and their particular epidemiological condition. 
The male partner/spouse is barely mentioned which reinforces in health care professionals the concept regarding gender issues. Man is seen as powerful and women as a reproductive being. In situations of violence, there is a stereotyped vision in which women are seen as unprotected and submissive whereas men are seen as powerful and strong ${ }^{(13)}$.

This explains the gender differences that emerge within a capitalistic society in regards to maternity and paternity; and highlights the various conflicts that need to be discussed about this reality. For the male adolescents, paternity means increased responsibility, the obligation to work and loss of freedom(19). Many couples who would like to participate are prevented by the work scheduling conflict in which they need to be integrated. It is important for healthcare professionals to accommodate their practices by proposing new strategies to involve the father in the process of pregnancy and birth; and to take into account the expectations of the couple itself.

The professionals that were interviewed reported that they developed and established a bond with these pregnant women in which trust and respect were present. Thus, this bond facilitated the intervention process with adolescents and their families.

The main facility is the bond (E12).

There was mistrust, but we can overcome it, talking a lot, showing her that I was a friend, a professional (E2).

A survey in Alfenas-MG with 24 nurses showed that the development of key skills in obstetrics during basic nursing education can facilitate greater inclusion in obstetric care ${ }^{(20)}$. These skills emphasized handling of the best position for the woman to give birth, care for the perineum and the quest to have an interventional and humanized model.

Thereby, it is important that the health care team establishes a bond with the pregnant adolescent and with the family. Health care team should establish a support network; build trust in order to establish a therapeutic relationship to assist in the care of the childrearing process ${ }^{(21)}$.

The relationship between health professionals and women victims of violence will be only effective if there is an organizational change in both the health system and type of care, because neither professionals nor services are prepared for both an adequate attention and quality intervention $^{(16)}$. Thus, to understand domestic violence as a complex phenomenon that needs to be addressed in its uniqueness and multidimensionality, it is necessary to build a larger and integrative nursing care ${ }^{(22)}$.

\section{Conclusions}

The present study demonstrated that the lack of education and training of health care professionals on issues related to domestic violence, as well as personal biases of each professional in dealing with this theme, potentiated the weaknesses of these professionals in the identification and intervention process in cases of domestic violence while providing health care services.

Healthcare professionals have difficulties to identify and intervene in cases of violence against women and these difficulties have been observed in their statements, but it has been also determined by the low number of reported cases of domestic violence, which makes this phenomenon invisible to society, although it exists. These difficulties are accentuated when the woman is pregnant and specially if the pregnant woman is an adolescent. Healthcare professionals' prejudice and moral values complicate further these difficulties.

In addition, some healthcare professionals provide care through working processes that emphasize the biological aspects of the subject and fail to identify the overall health needs of these patients.

One of the salient aspects, mentioned by healthcare professionals that contributed to comprehensive care, which met the needs of these pregnant women, was the establishment of bonds between the family, adolescent and pregnant woman with the prenatal consultation team. We believe, that this type of care could contribute to the process of identification and intervention by health care professionals in cases of domestic violence.

Although this was not the focus of the study, it was an important finding since other studies could be developed from this perspective. Taken all together, this study enabled a more extensive view of domestic violence which has been an issue of great importance in women's health care, it also enabled knowledge and understanding of the working processes of medical and nursing professionals who are part of the Family Health Strategy and who still focus their practice in the biological aspects of it; and finally this study gave evidence of invisibility of violence in this vulnerable age group.

It is worth highlighting that the working process of health care professionals needs reformulation in regards to the coherence of the goals of the Family Health Strategy. Thus teaching institutions, health services and health care professionals need to think about new strategies in order to strengthen the principles of the 
Brazilian Unified Health System, and subsequently how to enable comprehensive and quality care for all citizens.

Finally, it is an educational institution's duty to form better health professionals and to capacitate all health care workers from different areas of service; and it is government's duty to develop and implement policies aim to improve care for pregnant women who are victims of violence.

\section{References}

1. Gomes NP, Diniz NMF, Araújo AJS. Compreendendo a violência doméstica a partir das categorias gênero e geração. Acta Paul Enferm. 2007;20(4):504-8.

2. Carvalho-Barreto A, Bucher-Maluschke JSNF, Almeida PC, De Souza E. Desenvolvimento humano e violência de gênero: uma integração bioecológica. Psicol Reflex Crit. 2009;22(1):86-92.

3. Durant JG, Schraiber LB. Violência na gestação entre usuárias de serviços públicos de saúde da Grande São Paulo: prevalência e fatores associados. Rev Bras Epidemiol. 2007;10(3):310-22.

4. Audi CAF, Corrêa AMS, Turato E, Santiago SM, Andrade MGG, Rodrigues MSP. Percepção da violência doméstica por mulheres gestantes e não gestantes da cidade de Campinas-SP. Ciênc Saúde Coletiva. 2009;14(2):587-94.

5. Secretaria Municipal de Saúde de São Paulo. Encarte Técnico Assistência Obstétrica e Perinatal. São Paulo: Prefeitura da Cidade de São Paulo; 2007.

6. Ministério da Saúde (BR). Política Nacional de Atenção Integral à Saúde da Mulher: Princípios e Diretrizes. Brasília: Ministério da Saúde; 2011.

7. Granja E, Medrado B. Homens, violência de gênero e atenção integral em saúde. Psicol Soc. 2009;21(1):25-34. 8. Egry EY. Saúde coletiva: construindo um novo método em enfermagem. São Paulo: Ícone; 1996.

9. Fonseca RMGS, Guedes RN, Zalaf MRR, Venâncio KCMP. The gender research in nursing production: contributions of the Gender, Health and Nursing Research Group from the University of São Paulo School of Nursing. Rev Esc Enferm USP. 2011;45(spe 2):1690-5.

10. Fiorin JL. Elementos de análise do discurso. São Paulo: Contexto; 2005.

11. Jaramillo DE, Uribe TM. Rol del personal de salud en la atención a las mujeres maltratadas. Invest Educ Enferm. 2001;19(1):38-45.

12. Salcedo-Barrientos DM, Gonçalves L, Oliveira Junior $M$, Egry EY. Violência doméstica e enfermagem: da percepção do fenômeno à realidade cotidiana. Avanc Enferm. 2011;29(2):353-62.
13. Lettiere A, Nakano AMS, Rodrigues DT. Violence against women: visibility of the problem according to the health team. Rev Esc Enferm USP. 2008; 42(3):467-73.

14. Warshaw C, Ganley AL. Improving the health care response to violence. A resource manual for health care providers. San Francisco: Family Violence Prevention Fund; 1998.

15. Apostólico MR, Nóbrega CR, Guedes RN, Fonseca RMGS da, Egry EY. Characteristics of violence against children in a Brazilian Capital. Rev. Latino-Am. Enfermagem. 2012; 20(2):266-73.

16. Andrade CJM, Fonseca RMGS. Considerations on domestic violence, gender and the activities of family health teams. Rev Esc Enferm USP. 2008;42(3):591-95. 17. Ministério da Saúde (BR). Saúde da Família: Uma estratégia para a reorientação do modelo assistencial. Brasília (DF): Ministério da Saúde; 1997.

18. Lei 8.069 de 13 de Julho de 1990 (BR). [Internet]. Dispõe sobre o Estatuto da Criança e do Adolescente e dá outras providências. Presidência da República. Casa Civil. 13 jul 1990. [acesso 6 ago 2012]. Disponível em http://www.planalto.gov.br/ccivil_03/leis//8069.htm

19. Almeida AFF, Hardy E. Vulnerabilidade de gênero para a paternidade em homens adolescentes. Rev Saúde Pública. 2007;41(4):565-72.

20. Leite EPRC, Clápis MJ. A participação dos profissionais de enfermagem na assistência às parturientes no município de Alfenas, Minas Gerais. Cogitare Enferm. 2010;15(4):757-8.

21. Tomeleri KR, Marcon SS. Mãe adolescente cuidando do filho na primeira semana de vida. Rev Bras Enferm. 2009;62(3):355-61.

22. Backes DS, Viero M, Paim C, Carrêa E, Bopp J, Soldera N. A violência familiar na perspectiva do pensamento complexo. Avanc Enferm. 2011;29(2):225-33. 